\title{
The Diary of Thomas Giordani Wright: Apprentice Doctor in Newcastle upon Tyne, 1824-29
}

\author{
ALASTAIR JOHNSON*
}

Thomas Giordani Wright (1808-98), a prosperous doctor in Wakefield for most of his working life, started his long medical career as apprentice to Mr James McIntyre, Surgeon, in Newcastle upon Tyne. During the last three years of his apprenticeship (1826-29), before leaving to become a student at London University, he wrote his Diary of a doctor. ${ }^{1}$ The Diary, written not as a confidential and private journal, but rather as a report on the author's activities to be read "by family and friends", describes many aspects of his varied social life, including visits to the theatre, concerts, parties, dances and holidays. It also gives a detailed account of his work as a doctor. Although only eighteen years old when he began his Diary, and without any formal qualifications, Wright was already acting as an assistant in a busy medical practice. In this position he had responsibilities for his "own" patients, mainly coal miners and their families in villages around Newcastle. His Diary was used to record many of his cases and to comment in detail on the running of McIntyre's practice: the management, the organization of transport, the communication with patients, and the interactions between master, assistants and apprentices. As well as relating day-to-day events, Wright included sections, entitled 'My Autobiography', that describe his experiences up to the time he began his Diary: his youth in Stockton-on-Tees, his schooldays and some unhappy months indentured to a doctor in Darlington, his early experiences in Newcastle, and a winter session as a medical student in Edinburgh. ${ }^{2}$

This article, which concentrates mainly on Thomas G Wright's medical experiences in Newcastle between October 1826 and April 1829, highlights the Diary as a detailed primary source of information about the training and work of a medical apprentice in a growing industrial town in the early nineteenth century.

* Alastair Johnson, BSc, PhD, 8 Woodlands, Ponteland, Newcastle upon Tyne, NE20 9EU.

I thank Dr Alec Campbell and Dr David GardnerMedwin for their help and advice.

\footnotetext{
${ }^{1}$ The original MS of the Diary, was found in Nanaimo, British Columbia, Canada, in 1985 and was donated to the City of Newcastle upon Tyne by the Nanaimo Historical Society in 1990 . It is now held by The Tyne and Wear Archives Service, Blandford Square, Newcastle upon Tyne, catalogue number DX 47/1/1-9. The Diary was written in twelve separate home-made booklets, referred to as "volumes" by the author; nine of these have survived, containing altogether over 110,000 words.
}

They cover the periods October 1826 through August 1828 and March through April 1829. The fate of the missing volumes, presumably covering the period from September 1828 through February 1829, is not known. A transcription of the full text of the Diary is in course of publication: Alastair Johnson (ed.), The diary of Thomas Giordani Wright: Newcastle doctor, The Surtees Society, vol. 205. Extracts from the Diary have been published: Alastair Johnson (ed.), Diary of a doctor: surgeon's assistant in Newcastle upon Tyne 1826-1829, Newcastle, Newcastle Libraries, 1998.

${ }^{2}$ In the Diary MS the autobiographical chapters appear at irregular intervals between April and October 1827. 


\section{The Diary of Thomas Giordani Wright}

\section{Experiences in Newcastle and Edinburgh before the Start of the Diary}

Wright was indentured as "House-Pupil" to Mr James McIntyre ${ }^{3}$ in March 1824 for a fee of $£ 150$. Later, in his Diary, Wright commented on the agreement that had been made before he signed on:

Mr McIntyre's plans were that I should be on a footing of equality with a youth who had been with him about six weeks; that in rotation I should enjoy the privileges usual in his surgery viz. that of going to attend lectures one session during my term with him, and after that of becoming bona fide his assistant in the full practice of his ten collieries, (one has since been added); with, of course, the frequent benefit of his observations and instruction. ${ }^{4}$

Two weeks after signing, Wright was installed in the house of his new master and was soon busy with his new duties: making up prescriptions and delivering them, attending patients with Mr McIntyre and helping to dress wounds. The promised opportunity to attend a medical school arose about sixteen months after the indentures had been signed. With a choice between London and Edinburgh, the latter was selected, being "advised by Mr McIntyre and other professional friends as the best elementary school".

The account of Wright's winter session in Edinburgh (1825-6) was written in 1827, about a year after he returned to Newcastle. ${ }^{5}$ It gives information about the courses he attended: "Dr Hope, Professor of Chemistry; Dr Knox's lectures on Anatomy \&c and his dissecting rooms; Mr Liston's lectures on Surgery; and Dr Thompson on Practice of Physic", as well as about his social life and his relationships with his teachers. ${ }^{6}$ His friendship with Dr Robert Knox, then at the height of his career, is of particular interest. Wright corresponded with Knox after returning to Newcastle and, in 1829 after the Burke and Hare scandal, ${ }^{7}$ he wrote extensively about the case in his Diary. ${ }^{8}$

\footnotetext{
${ }^{3}$ The earliest known reference to James McIntyre is in the Directory for Newcastle upon Tyne and Gateshead, Newcastle, Thompson, 1824, p. 29 , where he is listed as a surgeon. McIntyre became MRCS in 1830, after he was already well-established in his Newcastle practice, see Examinations Book, Royal College of Surgeons (London), 4/6/1830. In 1831 , he was elected as Honorary Surgeon to Newcastle Infirmary, see G H Hume, The history of the Newcastle Infirmary, Newcastle, Andrew Reid, 1906, pp. 99-102. McIntyre was still in practice in Newcastle when he died in Cecil Street, London, after a short illness on $8 / 5 / 1837$, see Newcastle Courant, 19/5/1837. McIntyre was known in medical circles for a splint, invented for the treatment of fractured limbs, that he described in a paper published in 1825, see RCS Library, Tract 675; McIntyre's splint is also discussed in T Herbert Barker, 'On the treatment of fractures of the lower extremity', Lancet, 1837-8, i: 81-6; idem, 'Cases in illustration', ibid., pp. 111-15; T G Wright, 'Dr Wright on fracture apparatus', ibid., ii: 202-3.

${ }^{4}$ Diary, Autobiography, ch. 13.

${ }^{5}$ Diary, Autobiography, chs 15-17.

${ }^{6}$ During his time in Edinburgh, Thomas Wright was one of the set of students known as "Occasional Auditors" that had always formed a significant
}

fraction of the students at the University-about 54 per cent in the $1820 \mathrm{~s}$; like Wright, such students often stayed for only one session, and left without acquiring any formal qualifications at the University. See Lisa Rosner, Medical education in the age of improvement: Edinburgh students and apprentices, 1760-1826, Edinburgh University Press, 1991.

${ }^{7}$ Burke and Hare murdered at least 15 people in Edinburgh during 1828 and sold the corpses of their victims for medical dissection. Burke was tried, found guilty of murder, hanged and publicly dissected; Hare turned King's evidence and was released. This notorious case and its effect on Robert Knox, whose school of anatomy had purchased at least some of the bodies, have been the subject of much discussion over the years. See, e.g., Isobel Rae, Knox, the anatomist, Edinburgh and London, Oliver \& Boyd, 1964; Ruth Richardson, Death, dissection and the destitute, London, Penguin Books, 1988. pp. 131-41.

${ }^{8}$ Diary, 24/3/29, 30/3/29. Wright's comments show that he had a clear conception of the issues raised by the Burke and Hare case, particularly the question of whether anyone could tell if a "subject" had been murdered. From his personal knowledge of Knox's character, he considered it unthinkable that Knox could have been in any way knowingly 


\section{Alastair Johnson}

Wright left Edinburgh and returned to Newcastle at the end of April 1826. Being in a poor state of health after his time away, he was allowed to go home for a summer holiday. He was finally back in Newcastle to take up his duties, now as an "Assistant to $\mathrm{Mr}$ McIntyre”, in mid-August 1826. He began his Diary about six weeks later.

\section{Apprentice and Assistant}

At the time of the Diary, Newcastle was a fast-growing industrial town, with a population of about 40,000. The chief town and business centre of the Tyneside region, it was famous for its coal mining, but also had other important industries, including pottery, glass-making and chemicals. ${ }^{9}$ In 1826, Mr McIntyre's main premises in Newgate Street included living accommodation, main surgery, and stables. Although close to the town centre, these premises were old-fashioned and inconvenient, and in July 1828 a move was made a short distance to Eldon Square, part of a new, superior housing development still under construction at that time. Mr McIntyre had another surgery with living quarters close to a coal mine at Backworth, a village about seven miles from Newcastle.

Most of McIntyre's patients were coal miners and their dependants, living in scattered mining villages around Newcastle. It is evident from the Diary that McIntyre had a good relationship with John Buddle, manager of Wallsend Colliery and joint owner of the Backworth colliery, which must have been an important factor in the prosperity of the practice. ${ }^{10}$ Life and work in the north-east mining districts in the early nineteenth century have often been described and discussed. ${ }^{11}$ The contract system of employment was still in operation, with men being bound to their employer for a year after being hired. Digging and moving coal was demanding and dangerous work, in restricted space lit only by safety lamps. As shown by incidents in the Diary, there were many possible causes of accidents including gas explosions, falls of coal and rock, and encounters with trolleys. However, in some respects miners were better off than many other workers at that time. Their wages were above average, at least in times of economic prosperity, and there were some fringe benefits with the families of injured miners being helped. ${ }^{12}$ Also, as the Diary reveals, medical help was available to at least some of the workers.

implicated in the crime of murder, an opinion shared by many of Knox's students at the time (see Rae, op. cit., note 7 above). Wright had brought his Diary to an end before it became apparent that the career of Robert Knox had been seriously damaged by the Burke and Hare affair: his later views on the subject are not known.

${ }^{9}$ For the historical background to Newcastle and the Tyneside region, see, e.g., S Middlebrook, Newcastle upon Tyne: its growth and achievement, Newcastle Chronicle and Journal, 1950, particularly chs 15 and 16, and Norman McCord, North East England: an economic and social history, London, B T Batsford, 1979.

10 John Buddle (1773-1843) became manager of Wallsend Colliery in 1806. One of the foremost mining engineers in the country, he made many innovations in mining and was widely employed as a consultant, see, e.g., Richard Welford, Men of mark 'twixt Tyne and Tweed, 3 vols, Newcastle, Walter Scott, 1895, vol. 1, p. 425.

${ }^{11}$ See, e.g., McCord, op. cit., note 9 above, p. 38 ff.

12 John Buddle (see note 10 above), in evidence to the Select Committee on the Coal Trade, The state of the coal trade in the United Kingdom, London, 1829 , p. 29 , stated that men on a 12 month contract earned between 14/- and 40/- a week. They were paid $2 / 6$ a day if there was no employment for them, otherwise they were on piece work. They were provided with a house and fuel for $3 \mathrm{~d}$ a week. Buddle illustrated the "extent of humanity" of the employers by pointing out that the consequences of accidents were mitigated because "cripples were given employment if possible" such as "boys work e.g., trapping and furnace keeping". Also "widows homes and fuel continued" and a "remaining young child, of 6,7 , or 8 years, was given employment at advanced wages". 


\section{The Diary of Thomas Giordani Wright}

At the time Wright began his Diary in 1826, Mr McIntyre's staff consisted of two assistants and three apprentices in addition to Wright, who, although still indentured, was also acting as assistant. One of the assistants, John Gibson, was a son of Taylor Gibson, the proprietor of a well-established chemist and druggist firm with a shop in Newcastle. ${ }^{13}$ John had "returned to the practice, from studies in London" in 1824, shortly after Wright signed his own indentures. Although John Gibson's qualifications are not stated, he was highly respected by Wright, who benefited from his medical knowledge and experience. On the other hand, Wright had little to do with Mr Cochrane, the assistant at the Backworth surgery-described as a "low-bred Scotchman". One of the apprentices, William King, had been indentured shortly before Thomas Wright. However, Wright was given the first chance to take study-leave and, subsequently, to assume the responsibilities of an assistant. Remarks in his Diary, show Wright being rather contemptuous of King, describing him as an "ill-educated lad . . . a simple but good-natured fool", but he did admit that William was somewhat improved when he, in his turn, came back from a course in Edinburgh in 1827. The two junior apprentices, Greenwood and Spearman, turned out to be unsatisfactory recruits to the medical profession. Described as "reprobates" by Wright, they were both eventually dismissed for unruly behaviour and drunkenness.

Changes in personnel are mentioned as the Diary proceeds. John Gibson was disabled by a fall from his horse and left in 1827. A new junior apprentice, Grey, was engaged in 1828. A new, qualified partner, Dr Morson, ${ }^{14}$ entered the practice some time after August 1828. Just before Wright was due to leave Newcastle, his replacement, called Leith, was recruited: "a rawish looking scotch youth fresh from Edinburgh, where he has been two winters under Dr Knox".

Wright summarized his duties in 1826 as "having charge of six collieries around Newcastle and the inferior practice of the house". These collieries were in two main groups: Elswick and Benwell to the west of Newcastle, and Heaton, Byker, Walker and Wallsend, to the east. Some patients were able to attend the surgery in Newcastle for medicines, advice and sometimes treatment, but most of the cases mentioned were treated at their own homes and Wright's descriptions of some of the residences, good and bad, give a good idea of the conditions under which treatment had to be given to colliery patients. ${ }^{15}$

The exact distance travelled on rounds of patients is difficult to estimate without knowing details of the minor roads. Probably, a visit to Elswick and Benwell was a round trip of about 5 to 6 miles, and to the group between Newcastle and Wallsend about 8 to 10 miles. Quite often calls had to be made to scattered parts of the district on the same day, and on some of his longer rides, Wright himself estimated the distance as "18 miles or more". It has to be borne in mind, that Tyneside was already extensively industrialized, and it is likely that most of the places that Wright needed to visit were linked by reasonably good roads or riding paths. For example, he was able to use the North Shields turnpike to get to within a mile or two of the mining villages in the Wallsend area, and

\footnotetext{
${ }^{13}$ For details of Taylor Gibson's business, see W A Campbell, 'Pharmacy in Old Newcastle', in David Gardner-Medwin, Anne Hargreaves and Elizabeth Lazenby (eds), Medicine in Northumbria, Newcastle, The Pybus Society, 1993, ch. 18.

14 There is no information about Morson's
}

background in the existing Diary MS but it is known from other sources that Walter Skerret Morson, MD, was born about 1802 and died in Newcastle in 1832 , aged 30 .

${ }^{15}$ See, e.g., Diary, 4/1/28, 25/4/28, 25/5/28. 


\section{Alastair Johnson}

those to the west, Benwell and Elswick, were not far from main roads. This meant that most of the patients could be reached on horseback in less than an hour from the surgery in Newcastle. Visiting was made easier because many of the patients lived in small, clustered communities, often even in the same row of houses. This meant that travel-time in this industrial practice would have been much less than in some of the country practices that have been described, ${ }^{16}$ making it feasible, at a push, to see 20 to 30 patients in a day.

The smooth running of the wide-spread practice was critically dependent on having reliable horses. ${ }^{17}$ For most of the time Wright was with him, McIntyre kept only two horses at Newcastle and one at Backworth. This was barely adequate, and there were many crises when the work had to be curtailed, or at least reorganized, because one or more of the horses was out of commission. Mr McIntyre had first claim, so Wright then usually had to visit patients on foot. The only alternative, sometimes used to visit the Wallsend area, was to hire one of the gigs that operated a service along the Shields turnpike: on one occasion Wright mentions that Mr McIntyre gave him half a crown to pay his fare. McIntyre did have a private gig, which seems to have been brought into use mainly when it was necessary to transport two of the staff at the same time, recruiting one of the horses normally used for riding. Wright often comments on the lack of adequate transport, but no significant improvement came until after August 1828 in spite of horses being traded from time to time. By March 1829 things were looking up, with a "stud of 4 horses" and Wright proudly riding a "bay charger". This general improvement seems to have coincided with expansion of the practice during 1828 , including the move to Eldon Square, the entry of a partner and an increase in patient numbers.

Wright conscientiously recorded the "numbers of new patients", in his Diary nearly every week; by the end of his time in Newcastle the total had reached 2896. These patients are invariably divided into two groups: "colliery and private" and "sick". Wright mentions that "sick" are "patients subscribing to Mr Mcl" but does not spell-out exactly what was meant by "colliery and private". Presumably these were non-subscribers who would be billed for treatment received, the account being settled either by a colliery for its workers, or by the private patient. The Diary sometimes mentions entries being made in the "day book" and it appears that daily records were kept of amounts owed, with accounts being sent out annually. Making up the accounts towards the end of the year was one of Wright's responsibilities, a task he found irksome and time consuming. Unfortunately, Wright gives no details in his Diary of the basis of charges or of the actual amounts patients paid. ${ }^{18}$ Although these omissions in an otherwise detailed description of his work might seem

\footnotetext{
${ }^{16}$ See, e.g., John Kirkup, 'Edward Jenner's 1794 accompt book for the pocket or desk', Med. Hist., 1996, 40: 487-98.

${ }^{17}$ For a discussion of doctors' transport and its problems, see Irvine Loudon, Medical care and the general practitioner, Oxford University Press, 1986, pp. 117-25.

18 Visiting fees (excluding medicine) for Newcastle $1830-31$ of between 5 and 10 shillings have been reported, see Anne Digby, Making a medical living, Cambridge University Press, 1994, pp. 148-51; see also Loudon, op. cit., note 17 above, pp. 256-66. It appears, from the Diary that McIntyre charged for visits and for medicines, although this
}

may not have been done by all local practitioners. For example, a Newcastle doctor, in a paper delivered to the Medical Society of Newcastle in 1824 , complained that many doctors were obliged to derive most of their income from the sale of medicines, with a "consequent loss of dignity and a tendency to over prescribe and over charge". He proposed that there should be fees for visits and suggested a meeting of the town's practitioners to decide the level of fees. See T M Greenhow, 'Hints towards the adoption of an improved principle of remunerating the surgeon apothecary or general practitioner in medicine', Lit. and Phil. Society of Newcastle upon Tyne, Tracts, vol. 66, No. 3. 


\section{The Diary of Thomas Giordani Wright}

surprising, it may well be that Wright would have thought it indiscreet to reveal detailed financial information.

Between the start of the Diary in October 1826 and the end of August 1828, the total number of "new patients" in a normal month (i.e., without holiday or other absence) varied between a maximum of about 130 and minimum of about 60 , with an average of about 90 . Patients were divided fairly equally between the two categories, with usually slightly more in the group "colliery and private" than in the group "sick". The only other numbers available are for March 1829, near the end of Wright's stay in Newcastle. Then the total number was 160 , significantly greater than the maximum for the earlier period. This increase is largely due to a higher number of "sick" (subscribers): 104, compared with the highest number of about 60 reached before August 1828. In fact, near the end of the Diary, Wright comments on the increase in the total number of subscribers in the practice (not just "his" patients): "In 1826 the total number of subscribers to the 'Sick' were Heaton 62, Benwell 2. In April 1829 the amount was Heaton 69, Elswick 34, Benwell 30, Walker about 56 families paying to Mr McIntyre." 19 As well as regularly recording the number of his "new patients", towards the end of his Diary Wright inserted a table showing the number of patients "on the books", giving an interesting snapshot of the practice at a time near the end of his stay in Newcastle. There were relatively few private patients on the books (38 out of the total of 153) and these were divided almost equally between "town" and "country". ${ }^{20}$ Wright was involved (with the partners, Morson and McIntyre) in looking after about half of the private patients (17); Morson and McIntyre dealt with the remainder (21) without Wright's help. Comparison of the number of "sick" (72) reported "on the books" with the total number of subscribers (176) suggests that just under half of the subscribers were actually having treatment in March 1829.

Dispensing was carried out at the surgery. Although Wright was no longer required to make up the prescriptions himself, this work usually being left to the junior apprentices, he had earlier had plenty of experience in this area which he described in a light-hearted, facetious essay entitled 'More Miseries'. 11

In the years of the Diary, most of Wright's working time was spent visiting patients and treating them at their homes. Normally, rounds to each of the different areas covered by the practice were made at least twice a week, but the visiting pattern was flexible, determined usually by demand, but sometimes by the availability of fit horses. News of an accident usually came by a messenger on horseback, and was responded to as soon as possible. If the accident seemed severe, Mr McIntyre would attend it, together with one or more of his underlings. Often however, Wright was sent alone, with instructions to report back if he needed help. There were a few night-calls, sometimes to cases that turned out to be trivial, but such demands were relatively rare, presumably largely because of difficulties in communication. The work-load varied greatly from day to day, depending particularly on the number of accidents and their severity. The staff could be worked off their feet or left, at slack times, wishing for "something interesting to do".

The first week of the Diary provides a fairly typical example of Wright's work. On Monday (2 October 1826), he had a round visiting surgical and medical cases in Benwell,

\footnotetext{
${ }^{19}$ Diary, 30 /4/29.

20 It is assumed that all the "town" patients were private; it is clear from the context that "country"
}

patients were those living in mining villages.

${ }^{21}$ Diary, 11/3/29. 


\section{Alastair Johnson}

Elswick and Felling: "patients doing well. Ol: Croton given great relief in a case which has every appearance of Worms, tho' none yet evacuated. It may yet be Dyspepsia tho' ... "; later in the day, at $6 \mathrm{pm}$, he was called out to an accident near Heaton. On Tuesday he visited Wallsend patients, one of them a man dying of "chronic hepatitis", and then had to go to the surgery at Backworth to take a message to Mr Cochrane. His patients at Benwell, Elswick and Heaton were visited on Wednesday: "all going on as it ought to be". On Thursday morning he escorted to the Quayside a visiting "young German physician", who was on his way to meet Mr McIntyre at Wallsend to "go down a coal pit": "I put on trowsers, thinking I should have to go nowhere on horseback, but was obliged to change costume for an accident at Battle Hill. A man got his foot hurt, nothing serious." On Friday: "rode to Elswick, Benwell \&c. A grand tea drinking given to all the old wives \& young women of Elswick, for assisting and in fact principally putting out a fire which endangered the new Pit. I was half an hour too soon, but was often invited to go in."

On Saturday morning Wright had to return to Elswick to attend to a burnt man ("not very severe") then he visited a town patient who had had "a violent cholera" and was complaining of head pains and vomiting her medicine. At $4 \mathrm{pm}$ he was called out to treat "a lad at Walker" who was haemorrhaging from a cut on the head, caused by an accident the week before. On his way home, Wright visited a lady "who had been brought to bed on Thursday" and "encountered a large cheese and a spirit bottle set out upon the table . . . A capital cheese it was." He also called again on the town patient he had seen that morning and found her much better. On Sunday he went to Wallsend to see a young lady with "Chlorosis" and also viewed the body of "a poor wretch who had fallen down the pit this morning ...".

\section{Interaction with other Medical Facilities in the Newcastle Area}

Although, like most provincial towns, by the early nineteenth century Newcastle had several medical establishments, including the Infirmary, the House of Recovery or Fever Hospital, and the Dispensary, there are very few references to any of these institutions in the Diary. ${ }^{22}$ Patients were sent to the Infirmary in only two out of all the cases mentioned: a woman with a bone in her throat went for consultation (and was dismissed without treatment), and an injured miner, who subsequently died, was sent immediately after an accident. The Fever Hospital is mentioned only once when a family, referred to as "former patients of McIntyre", was admitted.

Wright enrolled as a "perennial pupil" at the Newcastle Infirmary during the third year of his apprenticeship in August 1827, his father paying the fee of 5 guineas. ${ }^{23}$ His account of his experiences as a student there provides some information about the Infirmary as a teaching establishment. ${ }^{24}$ Wright gives the names of the physicians and surgeons he attended and mentions going on ward rounds, being present during admission of patients and operations, and making use of the Infirmary library. ${ }^{25}$ The day after enrolling, he

\footnotetext{
22 For an account of the foundation and the work done by the Infirmary, House of Recovery and Dispensary, see Fred Miller, 'Dr John Clark 1744-1805: the forgotten physician', in GardnerMedwin, et al. (eds), op. cit., note 13 above, ch. 7 .

${ }^{23}$ Diary, 3/8/28.
}

\footnotetext{
24 There was no medical school in Newcastle until after 1834

25 The Medical Library at the Newcastle Infirmary, established in 1819, comprised 940 volumes by 1827 . The subscription was one guinea annually, half that amount for students under medical
} 


\section{The Diary of Thomas Giordani Wright}

decided to keep a 'Hospital Case-book', separate from his Diary, to record the cases he encountered at the Infirmary. As far as is known, the case-book has not survived so an unfortunate consequence of this decision is a lack of detailed information in the Diary about Wright's medical experiences at the Infirmary.

Outside the institutions, health care was provided by a range of practitioners: 10 physicians and 43 surgeons are listed in a Newcastle trade directory for $1827 .{ }^{26}$ Although, with a few exceptions, ${ }^{27}$ little is known about their status or their work, it is likely that there was considerable competition for clients. Wright often expresses satisfaction at the growth of the McIntyre practice and sometimes mentions patients who have transferred from other practitioners. One of these was a lady who had been satisfactorily treated for tape-worm by Wright:

She subscribes to \& had been previously treated by "Mr Wood Surgeon, Bonesetter \& Druggist" Gateshead. She is quite well by the use of some tonic aperient powders, and requests her bill, which she declares she will pay cheerfully!! ${ }^{28}$

Occasionally, collaboration with other practitioners is mentioned. For example, James Church, House Surgeon at the Newcastle Infirmary from 1817 to $1837,{ }^{29}$ was occasionally called on to help with accident cases, but there is no mention of whether or not he was paid for these services. Wright became friendly with at least one of the other Newcastle surgeons: “ . . . Mr Henzell Surgeon tho' I have never been introduced to him or spoke before stepped out of his road off the pathway in Dean Street today to tell me it was a sharp morning or something of that sort." 30 The relationship developed, and in the following months, Wright often mentions meeting Henzell on social occasions; he instructed Henzell in playing the flute, and referred to him as "my friend". On one occasion, Henzell was consulted professionally when Wright was attending a boy who had a fractured thigh and head injuries.

Quacks and irregular practitioners, of whom Newcastle had its share and whose services were widely advertised in local newspapers and elsewhere, are not specifically mentioned in the Diary. ${ }^{31}$ Nor does Wright comment on the sources of medical supplies used in the practice: medicines for home use were readily available from one or other of the 32 chemists and druggists as well as from other outlets. ${ }^{32}$

officers at the Infirmary, see W Parson and W White, History, directory and gazetteer of Newcastle, Durham and Northumberland, Newcastle, W White, 1827, vol. 1, p. xciv.

26 Ibid., pp. 122 and 125.

27 Some of the successful Newcastle doctors have been described by Dennis Embleton (1810-1900), who was an apprentice doctor in Newcastle at about the same time as Wright, see D Embleton, 'Biographical notices of members of the Philosophical \& Medical Society of Newcastle 100 years ago', in Proceedings of the Northumberland and Durham Medical Society, Session 1890-91, pp. 178-210. John Snow (1813-1858), later famous for his work on anaesthesia and the epidemiology of cholera, was also an apprentice in Newcastle in
1827, see Anthony Ashcroft, 'John Snow-Victorian physician', Gardner-Medwin, et. al. (eds), op. cit., note 13 above, ch. 16.

${ }^{28}$ Diary, 9/10/26. The abandoned doctor was probably James Wood, 24 High Street, Gateshead, see Parson and White, op. cit., note 25 above, p. 125.

${ }^{29}$ Hume, op. cit., note 3 above, p. 145.

${ }^{30}$ Diary, 27/1/27. Probably C R Henzell, surgeon, 81 , Percy Street, Newcastle, see Parson and White, op. cit., note 25 above, p. 42.

31 Wright was later to campaign against the indiscriminate use of opium preparations, cf. T G Wright, $A$ lecture on quack medicines, delivered to the Wakefield Mechanics Institution, 20/2/1843, London and Wakefield, R Groombridge, 1843.

${ }^{32}$ See Campbell, op. cit., note 13 above. 


\section{Alastair Johnson}

\section{Surgical and Medical Cases}

About 100 different surgical cases in which Wright was himself directly involved are mentioned in the Diary; only 5 of these were not caused by accidents. The few nonaccident surgical cases usually involved private patients and were relatively minor. ${ }^{33}$ They included: taking "a tumour off a persons eyelid", a "strumous inflammation of the finger \& hand" (treatment not described), a "hip-disease" (treated by "making an issue in the thigh" and, later, by a "powerful blister"), a boy with "spontaneous displacement of his patella" (nothing could be done to keep the patella in the correct position: the boy, who was "able to walk a little" was "ordered off to the seaside for his general health"). Dental treatment was carried out, as is apparent from a reference to a purchase of tooth forceps, but there are no references to this in the Diary apart from one case where Wright experimented with "Mr Fay's summary method of tooth drawing by nipping off their bodies with his awful looking forceps." 34

Of the 95 or so surgical cases described that resulted from accidents, all but about 5 involved miners or people working around the mines. Although not all the mining injuries handled by the practice are described in the Diary, it is possible to get an idea of the total number of cases because, in 1829, Wright was asked to make "an average list of accidents at $\mathrm{Mr}$ McIntyre's collieries in order to estimate the comparative liability of pitmen to danger". ${ }^{35}$ He summarized the information, obtained by "a weary study of the day books ... page by page", in two tables that he copied into his Diary in April 1829. These tables give the number and nature of the accident injuries at each of 6 collieries (Benwell, Elswick, Felling, Heaton, Walker, Wallsend). For 1826 and 1827 respectively, the total number of accident cases at all these collieries $(374,248)$ are detailed as simple fractures $(19,10)$; compound fractures $(6,5)$; dislocations $(3,4)$; severe wounds, lacerations $(112$, $25)$; bruises, sprains, contusions, minor accidents $(202,170)$; burns $(17,6)$ injuries of the eye $(3,2)$; ophthalmia $(12,26)$. Against "ophthalmia" there is the note: "From the noxious effluvia while sinking \&c. Some of the men were attacked three or four times with this disease". Footnotes to the table give a little more detail about the injuries for 1826 , for example, 4 simple fractures at Benwell were: "2 arm, thigh, clavicle". Wright also appended a "report" to his table for 1827 . This pointed out that only the more serious cases had been included, that a "great number of medical complaints which arise from inhaling the foul gas, generally more or less mingled with the underground atmosphere" had been omitted, that there had been no deaths and that, apart from one case of a compound fracture, "all are again following their usual employment in robust health and vigour".

The cases described in detail in the Diary text add significantly to the bare statistics in the tables, providing some graphic details of the injuries and showing how they were dealt with. Most of the incidents mentioned resulted in only one or two casualties, but occasionally Mr McIntyre's team had to cope with several simultaneous injuries. For

\footnotetext{
33 This accords with the conclusion, drawn from a study of eighteenth-century practitioners, that most provincial surgery in the pre-anaesthetic era was limited to the treatment of minor conditions, see Irvine Loudon, 'The nature of provincial medical practice in eighteenth-century England', Med. Hist., 1985, 29: 1-32.
}

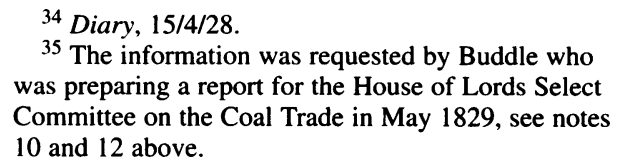

35 The information was requested by Buddle who was preparing a report for the House of Lords Select Committee on the Coal Trade in May 1829, see notes 10 and 12 above. 


\section{The Diary of Thomas Giordani Wright}

example, there was a mine explosion at Benwell on 27 October $1826 .{ }^{36}$ As soon as news of the disaster reached the surgery, McIntyre, Wright and Greenwood (an apprentice) rushed to the scene. Commenting on the event, Wright wrote:

The first person I saw was a lad with his thigh broke \&c which I left, while getting washed, to attend to a man severely burnt all over at Paradise Row. He I hope will recover. Just as we were leaving him, the cart brought home one of the remaining two, who were till then missing dreadfully burnt, and tho' he was properly dressed I doubt he will not survive long. The lad we first saw was then dressed. His right thigh was fractured, and that leg very much cut, his right clavicle started from its articulation at its sternal end. About 5 of the front teeth in the upper jaw completely knocked out; three of those in the lower jaw broken quite inwards, the lips cut, \& the face all scratched \& cut with the coals he had fallen (or rather been shot) amongst. The leg was dressed; the fracture reduced, then the dislocation of the clavicle, and lastly the teeth put right. The extremities were at first very cold, but by warm bricks \&c a more general warmth pervaded when we left him. Greenwood, from not returning, has, I suppose, (6 PM) been left to look to the burnt men. Several accounts have been in; the last just now says the man so dreadfully burnt is living yet.

The continuing treatment of some of the survivors is mentioned from time to time. For example about four weeks after the accident Wright wrote of one patient: "the burns are skinning rapidly, but it will still be a tedious case" and, after a further two weeks: "I removed all the plasters from my burnt patient at Benwell this morning and put him on a shirt-a thing he had not had on since the accident". At the same time he commented on the fracture case:

Hepplewhite's thigh is far from being so straight as I could wish, but it is his own fault. He could not be made to keep still when the bones were uniting, and it will be difficult if not impossible to make them any better now-the fracture was so high up that the splint would have little effect in keeping it steady. Mr McIntyre though hit upon an ingenious expedient to keep the bones as straight as might be notwithstanding the boy's restlessness. He bent the splint very much, and so suspended (as it were) the thigh from the knee. ${ }^{37}$

There are several descriptions of the management of compound fractures of the leg. For example, after being called out, just after 2 am, to an accident at Heaton in November 1827:

... [I] reduced the fracture, having cleansed the wound, and taken away, with the help of my scalpel, two tolerably large splinters from the tibia, laid the leg upon the splint, thus leaving all open for Mr Mcl's inspection, and yet having only the bandages to be put on should the position \&c be approved. When Mr McI came he ... said it was very well reduced and rather pouted at having been called out! $!^{38}$

Unfortunately, the initial optimism was unwarranted and Wright continued to report on this troublesome case at intervals. The last mention was at the end of July 1828, more than 8 months after the accident: "[The patient] has had a severe attack lately of inflammation

\footnotetext{
36 The disaster at Benwell is described in John Sykes, Local records, 2 vols, Newcastle, Sykes, 1833, vol. 2, p. 199: “An accident took place in the high part of Benwell Colliery near Newcastle, by which two young men, named Joseph Whitfield and William Peel, were killed instantly. Several men were injured. There were upwards of 100 men and
}

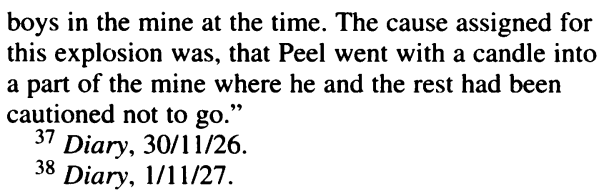

${ }^{37}$ Diary, 30/11/26.

${ }^{38}$ Diary, 1/11/27. 


\section{Alastair Johnson}

in his limb but it is today considerable abated. He gets out a little just to the door in an arm chair but is not able to use crutches". Two cases of compound fractures of the arm are mentioned. In both, amputation was avoided although, initially, it seemed that it might be necessary. There were no amputations of limbs in the practice in the period covered by the Diary.

There are descriptions of 4 cases of head injury with concussion and possible fractured skull. For these, diagnosis of the extent of injury was impossible, and comments on the cases reveal the doctors' uncertainty in knowing what treatment, if any, should be given. Usually venesection and/or leeching was carried out, and trepanning was sometimes used. In one case, a boy at Wallsend "received severe concussion of the Brain". About a week after the accident, his condition deteriorated. Although trepanning was proposed, the boy's father would not give permission for the operation and the boy died the next night. Permission was given for a post-mortem examination, which is described in detail. After seeing the true extent of the injury, Wright concluded that the operation would have served no purpose. He went on to justify their handling of this case.

Mr Abernethy in one of his last weeks lectures (vide "Lancet" June 9, 1827) says "there are some cases of injury to the head which would puzzle the devil himself I believe; and those are the cases of fractures of the base of the skull". This exactly bears upon the above instance. The patient had all the symptoms of concussion-so Mr McI did not bleed-but he had also evident signs of compression on the brain which called for venesection. As Abernethy says again "those cases are attended with a train of symptoms that would puzzle anybody. They are a mixture; sometimes like concussion sometimes like compression". I merely quote this in vindication of our character in being rather puzzled by the aforementioned case. ${ }^{39}$

Lacerations were common in mining accidents, with varying degrees of severity. The details of the treatment of some of the more serious ones are described. For example:

... about six oclock the Heaton Messenger came in-a lad had got his head cut at Heaton High Pit. I went out in quick time and a terrible cut it was. A part of the Scalp the size of my whole hand at least was completely detached in a flap,- - the cranium denuded of its periosteum for about a third of the wound and the periosteum in some places neatly dissected from both bone $\&$ integuments. After a deal of pains \& trouble I got the hair cut off, then shaved the head all round the flap and the flap itself clean. I washed the parts well and removed all the hair, dirt in the wound. A vessel bled violently, a branch of the occipital artery; so I threw a ligature around it and having brought the surfaces into as close apposition and inserted two sutures I applied adhesive plaster strips, a pledget, compress $\&$ bandage. My patient was easy when I left him and inclined to sleep, but roused himself a little to sing out for something to eat! I had given him 25 drops of $\mathrm{T}^{\mathrm{r}}$ Opii before dressing . . the whole operation took me an hour $\&$ half $\ldots{ }^{40}$

Wright commented on this case about two months after the accident: "that wound to my astonishment as well as the patients united by the first intention and was quite well in about 10 days!"

Cuts and fractures often occurred together, as in the case a man who

${ }^{39}$ Diary, 12/6/27. The Lancet quotation is from 'Lectures by Mr Abernethy on operative surgery', Lancet, 1826-7, 12: 289-97, on p. 296. It is interesting that this article is printed in the issue dated just three days before Wright's reference to it in his Diary.

${ }^{40}$ Diary, $15 / 12 / 26$. 


\section{The Diary of Thomas Giordani Wright}

... had got struck by a stone falling from the roof of the pit ... which first hit his head, and falling upon his legs had fractured the fibula of one, and cut the other down in a flap from a little below the knee to nearly the ancle, laying the shin bone bare for about 6 inches. . . [ [this wound] was closed by three sutures \& adhesive plaster ... I put it up very carefully but if it unites by the first intention, I shall consider it almost a miracle. It is the most extensive flesh wound I ever saw. After I had dressed it my patient complained very much of the other-the fractured limb. I of course could only apply lotion to it and lay it in a proper position. No leeches are to be had. ${ }^{41}$

Four days later, Wright was delighted to find that the wound had "united close" and he reported the cut "just about well" about 6 weeks later, although the fractured leg was still giving trouble.

"Bruises" ranged from superficial damage to serious injuries. A fatal case occurred in the first month of the Diary, when a "lad at Elswick got very much bruised". Wright prescribed 12 leeches for abdominal application, with castor oil and tincture of opium to be taken 2 hourly. The next day he reported there had been no improvement and McIntyre was consulted: ". . . give him some Croton oil pills then, you know you must get his bowels open; and some purging mixture". In the event, the lad died before more could be done. "Most probably a rupture of some of the viscera caused death."

Burns were common in mining accidents, but little detailed information about the treatment can be gleaned from the Diary. Wright mentions "dressing" burnt patients as well as changing the dressing, and comments that this could be painful for the sufferer but does not describe the materials used. Eventual "skinning" seems to have been regarded as a stage in recovery, before final "healing".

For many of the medical cases mentioned in the Diary, Wright described the symptoms, his diagnoses, and the treatment administered, and he sometimes copied out the full prescription for the medication. ${ }^{42}$ An example of the style of his reporting is a case first mentioned towards the end of August 1827.

There is an interesting and well-marked case of epilepsy on the books just now arising from worms. The boy about 7 years old some time ago got rid of one large worm but lately has been attacked every night and frequently during the day with fits. He has partially lost the use of the left side. $\mathrm{Mr}$ McIntyre ordered him some Jalap \& Calomel last week with a Rhubarb \& Magnesia mixture which being taken without effect. I yesterday prescribed the following on the supposition that more worms remain which are causing the disease.

The prescription given was for a mixture of powdered scammony, calomel, croton oil and sugar, to be taken each morning. Wright commented again on this case five days later.

The epileptic patient mentioned has found great benefit from the use of those Croton Oil powders. The paroxysms when I saw him on Friday - when he had taken four powders-had returned less frequently and the dejecta were extremely unnatural and tar-like. Thinking that $3 \mathrm{gr}$ of Calomel a day might be too powerful for a boy of his age I ordered the medicine to be repeated in a rather different formula.

${ }^{41}$ Diary, 20/4/27.

42 The style of the full prescriptions, 6 of which appear in the Diary, is similar to that used, about 20 years later, by John Snow (see note 27 above) for the prescriptions in his case books. A detailed description of Snow's prescriptions, which includes a glossary of the terms used, a description of drugs and preparations and of their effects is given by M P Earles, 'The prescription records', in Richard H Ellis (ed.), The case books of Dr John Snow, Medical History, Supplement No. 14, London, Wellcome Institute for the History of Medicine, 1994, pp. xliv-lvii. 


\section{Alastair Johnson}

The revised prescription is given: it omits the calomel but includes, instead, jalap and rhubarb powders. After two more days:

Ainesly's boy (Epilepsy) is better in regard to his original disease but I find his tongue very foul this morning but of a different appearance to the fur at first exhibited and which last had almost disappeared. This today shewn is a thick softish white coating whilst the former one was brown \& dry. I should judge the stomach now to be weakened by the severe medicines it has been necessary to use and have accordingly prescribed for him tonic medicine.... the last powders I ordered were sufficiently powerful taken once a day.

The prescription is given for the "tonic medicine" (containing gentian, peppermint water, ginger and rhubarb). A final comment on this case appears about a month later: "I rather pride myself on the treatment of this case which required to be pretty brisk. The boy is now perfectly well."

About 35 medical cases are described in some detail. The diseases encountereddiagnoses include chlorosis, colds, diarrhoea, dropsy, dyspepsia, fevers (scarlet fever, typhus, synochus), swollen glands, haemorrhoids, heart disease (angina), hydrothorax, measles, puerperal convulsions, worms-are typical of those prevalent at that time and, in general, the diagnoses and treatments used are in line with then current orthodox medicine. ${ }^{43}$ Nor are there any surprises in the medication mentioned, which includes many of the purgatives, emetics, sudorifics, febrifuges, antacids and soporifics then in general use. ${ }^{44}$

\section{Wright's Apprenticeship as a Training Experience}

The value of an apprenticeship in the training of a doctor, a matter of controversy throughout the period when the 1815 Apothecary Act was in force, has often been discussed. ${ }^{45}$ It was not unusual for apprentices to be treated merely as cheap labour, expected to serve out their time "in the shop", making up drugs and doing humble tasks. Although Wright had a taste of that type of apprenticeship at his first post in Darlington, ${ }^{46}$ his experience with Mr McIntyre in Newcastle was completely different. He did have training in drug preparation during the early years of his apprenticeship, but was visiting patients with his master from the first months, and by his third year he was doing the work of an assistant, often working independently. Wright sometimes mentions "being ordered" by Mr McIntyre to attend a patient or an accident, but he was clearly given a lot of responsibility for his "own" patients and was expected to visit them regularly and make his own decisions about their treatment. He was also directly involved in many aspects of practice management, such as planning visits to patients, handling the accounts, and supervising the training of junior apprentices. In addition, Wright had plenty of opportunities to build up his theoretical knowledge, through reading ${ }^{47}$ and attending

\footnotetext{
${ }^{43}$ See, e.g., Loudon, op. cit., note 17 above, pp. 54-65.

${ }^{44}$ See, e.g., Campbell, op. cit., note 13 above, pp. 266-7, also Earles, op. cit., note 42 above.

45 See e.g., Loudon, op. cit., note 17 above, pp. 176-80.

${ }^{46}$ Diary, Autobiography, chs 9 and 12.

${ }^{47}$ Medical works mentioned in the Diary include
}

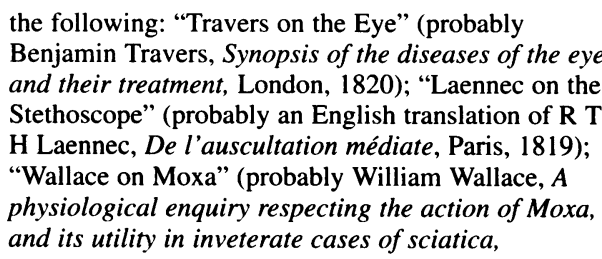

the following: "Travers on the Eye" (probably Benjamin Travers, Synopsis of the diseases of the eye and their treatment, London, 1820); "Laennec on the Stethoscope" (probably an English translation of R T H Laennec, De l'auscultation médiate, Paris, 1819); physiological enquiry respecting the action of Moxa, and its utility in inveterate cases of sciatica, 
courses, ${ }^{48}$ all the time he was at Newcastle. A further great advantage was being able to spend a session as a student in Edinburgh during his apprenticeship. Although, as was common at that period, Wright did not sit any examinations or obtain any paper qualifications in Edinburgh, his time there clearly was an invaluable experience, enabling him to learn from some of the leading medical figures of the day and to make many useful contacts. Later, during the final year of his apprenticeship, he was able to become a pupil at Newcastle Infirmary, further broadening his experience.

In spite of his work being sometimes very demanding, there were few occasions when Wright did not have some leisure time to pursue his many interests outside medicine, which included general reading. He often commented on the books he read, including philosophical works, poems, and fiction, as well as medical texts. For reading matter, he made good use of the local libraries, including that of the Infirmary, ${ }^{49}$ and, particularly, that of the Newcastle Literary and Philosophical Society, ${ }^{50}$ which also supplied him with current periodicals and newspapers.

\section{Master-Apprentice Relations}

Mr McIntyre, who allowed Wright a lot of responsibility early in his training, must have realized the benefits of having such a capable and dependable apprentice. On his side, Wright several times in his Diary acknowledged the advantages of working for Mr McIntyre, although he was by no means always uncritical of his master, whom he found haughty, abrupt, seemingly ever ready to criticize, and reluctant to give recognition for a job well-done. Although still indentured and strictly speaking unqualified, Wright was actually doing the work of a full-time doctor in the practice and he felt he was worthy of the title "Assistant to Mr McIntyre"; it irked him when he was referred to, or treated socially, as merely an "apprentice", with its low-status connotations.

McIntyre quite often left Wright in charge of the practice while he was away, on business or pleasure, sometimes for several days at a time. Wright apparently coped well with this, but often felt he was carrying an unfairly heavy load. After one absence of his master he commented:

In making up the lists of new patients for the last two weeks I find that out of the 29 entered last week, no less than 17 were subsequent to Mr McIntyre's leaving home on the Thursday. There have been 15 more booked this week previous to Mr Mcl's return making in all 44 new patients entered in his absence. ${ }^{51}$

lumbago, paraplegia, epilepsy, and some other painful, paralytic, and spasmodic diseases of the nerves and muscles, Dublin, 1827); "Bell's plates of the nerves" (Sir Charles Bell, A series of engravings, explaining the course of the nerves, London, 1816); "Johnson on the Stomach" (probably James Johnson, MD, An essay on morbid sensibility of the stomach and bowels, London, 1827); "Dr Clutterbuck's interesting work on the seat of fever" (probably Henry Clutterbuck, An inquiry into the seat and nature of fever; a second edition of this work was published in 1825); "M Broussais' counter opinions on the subject [of fever]" (F J V Broussais, Histoire des phlegmasies, ou, inflammations chroniques, possibly the 4th ed., published in Paris in 1826).

${ }^{48}$ Principally, lectures on science given by William Turner at the Literary and Philosophical Society, see R S Watson, The history of the Literary and Philosophical Society of Newcastle upon Tyne 1793-1891, London, 1897.

49 See note 25 above.

${ }^{50}$ See Watson, op. cit., note 48 above.

${ }^{51}$ Diary, 23/2/27. 


\section{Alastair Johnson}

Sometimes his resentment emerges:

Mr McIntyre returned from his trip to Edinburgh on Friday night and on coming home today I find him on a few days visit at Tynemouth on pleasure! If any surgeon but himself were to run away from his business as he does there would soon be a blank day book to look at, and an empty ledger to cash up. 52

Some of the medical procedures used by Mr McIntyre also came in for criticism. Following a case where a patient with "a pain in the side and bowels", had been given a particularly drastic course of purging and bleeding, Wright used his Diary to record his doubts about "the propriety of Mr McI bleeding so frequently".

The man was bled twice about a fortnight ago. Mr McI will say perhaps "the blood was cupped and buffy, a sure indication of venesection requiring to be repeated". Not always, my good master; the circulation will be restored to its tone when the bowels are put regular again, depend upon it. Another reason, may be you wish to weaken the patient, and thereby causing laxity of the intestinal fibre, in part remove the obstruction. . . I I am not very fond of bleeding with a foul stomach. First put all right there, then if disflammation is going on in the system to the lancet. Mr Liston' ${ }^{53}$ lancets do not see daylight often for months together, and yet (in his extensive practice) he says, "no one is more ready to use them when requisite and that freely too". ${ }^{54}$

Wright again drew upon the authority of his Edinburgh teacher in a comment on the treatment of wounds:

... a boy got a severe cut on the thigh. I inserted two sutures and the wound when I dressed it yesterday was looking remarkably well. Mr McI took occasion in my mentioning the accident to him to remark that "sutures are very seldom useful"! Mr Liston on the other hand whom Mr McI himself denominates "the first surgeon perhaps in the Kingdom" never uses "one atom" (as Mr L says) of adhesive plaster. He unites all his wounds by means of sutures!! I made no reply however to Mr McI. ${ }^{55}$

It must be said that, in spite of Wright's complaints, there are several indications that MacIntyre's practice was actually fairly well up-to-date. Examples are the awareness of recent medical literature, and use of the stethoscope, an innovation at the time. ${ }^{56}$

... I have a patient whose symptoms though by no means urgent rather puzzle me. I think there is some affection of the Heart or disease of the Ventricular Valves or Aorta. I will try auscultation if I have opportunity. Mr Church having been so polite as to return a stethoscope $\mathrm{Mr} \mathrm{McI} \mathrm{had} \mathrm{given} \mathrm{him}$ (he has now got several more) to me for my use. ${ }^{57}$

Wright spent some time in sole charge at the Backworth surgery while the assistant there was away in the summer of 1828 . He welcomed the opportunity to plan his own working routine without interference, and had time to think about the changes he would make if he were in charge of the practice. He considered the accommodation at Backworth inadequate, and felt that it should include a purpose-built residence with:

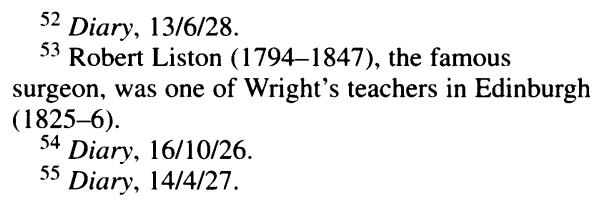

\footnotetext{
56 See, e.g., W F Bynum, Science and the practice of medicine in the nineteenth century, Cambridge University Press, 1994, pp. 37-42.

57 Diary, 12/12/26. Mr (James) Church, referred to here, was employed as House Surgeon at Newcastle Infirmary.
} 
pleasant gardens, stables, surgery \&c....Two assistants should be procured-one might suffice if I did not run off to Edinburgh, and all over the country very often;- members of the College and with genteel salaries perhaps 100 gns a year with board \& lodging in the family. One of these gentlemen to reside in the country and one at Newcastle. Three apprentices divided between the two places would be sufficiency. . . . The increase in practice which would follow such a step would amply repay the little extra expenditure; though an annual income amounting nearly to thousands ought to support an establishment which would then be decidedly the first surgical practice in the North! ${ }^{58}$

When his indenture period came to an end, Wright's views on Mr McIntyre softened considerably and they parted on good terms. Indeed, Wright was happy to go back to his old job in Newcastle for a short time in August 1829 to help out Mr McIntyre after one apprentice had been dismissed "after one of his continued debaucheries" and another "had ruptured a blood-vessel and gone away ill". Wright worked for about 10 days, mainly bringing the accounts up to date, and after leaving wrote: "Mr McIntyre who has shewn me the kindest attention during my visit made me a present of a superb silver lancet case enclosing 3 pearl lancets and inscribed JM to TGW."

\section{Thomas G Wright's Career after leaving Newcastle}

After completing his apprenticeship Wright became a student at London University, where he enrolled in October 1829. Brief notes that he wrote at the end of his Diary MS indicate the highlights of his student career: he became a Licentiate of Apothecaries Hall in February $1830^{59}$ and, after examinations, he was awarded silver medals in the "Classes of Physiology and Midwifery and an honorary Certificate in Surgery" in May 1831, and in January 1831 he was examined by "the Court of the Royal College of Surgeons", receiving his diploma as MRCS. ${ }^{60} \mathrm{He}$ was elected President of the London University Medical Society in 1830.

There is nothing in the Diary about Wright's life after he left London University in April 1831 , but a detailed picture of his whole career in medicine can be built up from other sources. He qualified for the MD degree at the University of Leyden in June $1831 .^{61}$ In 1833 he published a paper on cholera ${ }^{62}$ from Stockton-on-Tees, in which he indicated that he studied medicine in Paris in the summer of 1832, although no further details of this episode are available. In 1833 he settled in Wakefield and soon afterwards was appointed Honorary Physician to the Asylum and the Wakefield House of Recovery. ${ }^{63}$ Wright became a Licentiate of the Royal College of Physicians of London in 1841 and a Member in 1859. During his

${ }^{58}$ Diary, 1/8/28.

${ }^{59}$ List of persons qualified to practise as Apothecaries, London, 1840, p. 222.

${ }^{60} \mathrm{~A}$ list of successful candidates for the Diploma of Membership, MRCS, recorded by the Court of Examiners of the RCS (London) in the Examinations Book, 7/1/1831, includes Thomas Giordain [sic] Wright, Stockton upon Tees.

${ }^{61}$ The regulations for the MD degree at Leyden are described by R W Innes Smith, English-speaking students of medicine at the University of Leyden, Edinburgh and London, Oliver \& Boyd, 1932. Wright's MD thesis, which was defended on
11/6/1831, was published with the title Disceptatio medica inauguralis de scrofulosi: a copy, presented by Wright to Newcastle Infirmary Medical Library, is held by the Library of the University of Newcastle.

62 T G Wright, 'Remarks on the malignant cholera', Lancet, 1832-33, i: 625-9.

${ }^{63}$ Hilary Marland, Medicine and society in Wakefield and Huddersfield, 1780-1870, Cambridge University Press, 1987, particularly pp. 356-7, gives detailed information about T G Wright's career in Wakefield. See also obituaries of Wright in the $\mathbf{B r}$. med. J., 1898, i: 1493, and, e.g., the Wakefield Express, 28/5/1898. 


\section{Alastair Johnson}

years in Wakefield he built up a large private practice, which included many members of the local gentry, and when he retired he was presented with a testimonial "amounting to 900 guineas, by a large circle of friends" ${ }^{64} \mathrm{He}$ died in Wakefield in 1898, aged 90 . His funeral in Wakefield Cathedral "... was attended by nearly all the medical men in the city and suburbs, by many of the principal residents, and by representatives of several public bodies." 65

\section{Conclusion}

Thomas Giordani Wright served his apprenticeship in Newcastle at a time when the importance of general practitioners was not yet generally recognized, either in the structure of the medical profession or in much of the medical training that was available in England. ${ }^{66}$ The overall impression from his Diary is that Wright, an intelligent and lively young man who started with the benefits of a good school education and supportive parents, had an excellent training in his apprenticeship with Mr McIntyre which was very appropriate for a general practitioner of the day. The surgical side of the practice predominated, with most of the patients suffering from mining injuries, but there were also many medical cases, and the apprentice encountered most of the illnesses that were around at the time. As far as medical treatments were concerned, Wright was eager to familiarize himself with what was then best practice although he did not see medical knowledge as static and was on the lookout for improved techniques. He was prepared to experiment with variations in medication, attempting to match cause and effect, and keeping notes on the outcome in many cases. He also learned many of the non-medical skills needed by a successful doctor, such as keeping the accounts and controlling juniors. In the important area of patient-care, Wright, who seems to have been naturally conscientious and sympathetic, was allowed the time he needed to attend to his cases and there are many indications in the Diary that he was appreciated and well-liked by his patients.

Perhaps what emerges above all from the Diary is a sense of Wright's enthusiasm and of the pride and pleasure he took in learning his chosen profession, in spite of many vicissitudes. Although his training did not end with his apprenticeship, and he went on to acquire qualifications far above the minimum then required to practise medicine, his apprentice years with Mr McIntyre can be seen as the firm foundation for Thomas $\mathrm{G}$ Wright's very successful and worthy career as a doctor.

${ }^{64}$ Br. med. J., ibid.

65 The description of Wright's funeral fills several columns in the Wakefield Free Press and West Riding
Advertiser, and in the Wakefield Express, 4/6/1898.

${ }^{66}$ See, e.g., Loudon, op. cit., note 17 above, ch. 9. 